\title{
USE OF BIOSCREEN C FOR GROWTH OF MUCOR HIEMALIS IN DIFFERENT CARBON AND NITROGEN SOURCES
}

\author{
Sâmia Maria Tauk-Tornisielo*; Joelma Maurício Vieira; José Silvio Govone \\ Centro de Estudos Ambientais, Universidade Estadual Paulista, Rio Claro, SP, Brazil
}

Submitted: April 19, 2005; Returned to authors for corrections: March 09, 2006; Approved: October 13, 2006

\begin{abstract}
The automated Bioscreen C system was used for growth of four Mucor hiemalis strains isolated from the soil in the Juréia-Itatins Ecology Station (JIES), São Paulo state, in liquid culture media containing different carbon $(2 \%)$ and nitrogen $(1 \%)$ sources, $\mathrm{pH} 5.0$, at $25^{\circ} \mathrm{C}$, and agitated at $150 \mathrm{rpm}$ for 5 days. The medium containing only one nitrogen source had been added with $2 \%$ glucose. The readings were taken at $\lambda=540 \mathrm{~nm}$, at 2-hour intervals, up to five days. The results were compared using the Friedman Test ( $\alpha=5 \%)$. The best growth was obtained for strains M1, M2 and M3, reaching the log phase in 60 hours. The best carbon sources varied according to the strain, and yeast extract proved to be the best nitrogen source. Sodium acetate inhibited the growth of the four strains, being the M3 strain the most affected. The use of the automated system was very convenient for cultures in liquid media, as it is rapid and automated, providing a good technique for determination of the optimal environmental factors for growth of the filamentous fungi.
\end{abstract}

Key words: Mucor hiemalis, zygomycetes, automated systems, carbon and nitrogen sources

\section{INTRODUCTION}

Turbidimetric methods have been used to generate kinetic data for modeling by fitting non-linear regression functions to optical density (OD) (6). A rapid, more detailed test can be developed using Bioscreen, an automated system to measure microbial growth. This equipment has been used for many applications in microbiology, including basic research (1), studies on the effects of chemical compounds on the growth of microorganisms (5), quality control of culture media (3) and food products (6), determination of the lag time of individual cells (10), and others. The software converts kinetically measured optical density (OD) data into growth curves. The Bioscreen sample plates are sterile, disposable and can take up to 200 samples per test, enabling replication to be easily performed. This method eliminates the need for time consuming serial dilutions whilst also reducing the amount of test materials required.

During previous studies carried out at the Juréia-Itatins Ecology Station (JIES) in São Paulo, Brazil, aiming to improve knowledge on the biodiversity of the microbiota in the soil (9), 112 fungi species were isolated and are currently being studied with respect to their potential for producing macromolecules of interest to medicine and industry. Some of these strains present potential for production of enzymes, such as xylanase, and fatty acids, including $\lambda$-linolenic acid (GLA) (7).

The objective of the present study was to verify the effect of different carbon and nitrogen sources and $\mathrm{pH}$ on the growth of four strains of Mucor hiemalis isolated from the soil at the Juréia-Itatins Ecology Station (JIES), State of São Paulo, Brazil (9), employing the automated Bioscreen $\mathrm{C}$ system to measure these effects.

\section{MATERIALS AND METHODS}

\section{Inocula}

Four strains of Mucor hiemalis (M1, M2, M3 and M4) isolated from the soil in the Juréia-Itatins Ecology Station, SP, Brazil, at a depth of $0-15 \mathrm{~cm}(7)$, were stored at $4^{\circ} \mathrm{C}$ in test tubes containing malt extract medium. The inocula used in the study comprised

*Corresponding Author. Mailing address: Unesp - Centro de Estudos Ambientais - Av. 24-A, 1515 - Bela Vista. 05508-900. Rio Claro, SP - Brasil. Tel.: (19) 3534-0122. E-mail: seb@rc.unesp.br 
spore suspensions containing approximately $10^{6}$ to $10^{7}$ spores $\mathrm{mL}^{-1}$, counted in a Neubauer chamber, in a $0.85 \% \mathrm{NaCl}$ solution.

\section{Bioscreen C technique}

The strains were cultivated in the automated Bioscreen C system (Lab systems Helsinki, Finland), using a culture medium with $2 \%$ single carbon source or $1 \%$ single nitrogen source. As carbon sources, sodium acetate, fructose, galactose, glycerol, glucose, lactose, maltose, sucrose, sorbitol, or xylose were used. The nitrogen sources included yeast extract, peptone, ammonium sulfate, or potassium nitrate. In the culture media with a single nitrogen source, $2 \%$ glucose was used as the carbon source. The working volume in the wells of the Bioscreen plate was $400 \mu \mathrm{L}$, comprised of $360 \mu \mathrm{L}$ of culture medium and 40 $\mu \mathrm{L}$ of spore solution. The temperature was controlled at $25^{\circ} \mathrm{C}$, and the optical density of the cell suspensions was measured automatically at $540 \mathrm{~nm}$ in regular intervals of $2 \mathrm{~h}$, for five days. Before each measurement, the culture wells were automatically shaken for 60 seconds. The experiments were carried out in quadruplicate. The control tubes contained the tested culture medium without inoculum. The data were analyzed using a spreadsheet software (Excel 97) and calculating the averages of the quadruplicates for each type of culture medium. The averages were used to generate the growth curves for each strain studied, constructed as a function of the incubation time and the absorbancy of the culture medium, with the data plotted in 20-hour intervals. The results were submitted to the Friedman Test (11), with 5\% as significance level.

\section{RESULTS AND DISCUSSION}

Despite belonging to the same species, the four strains of Mucor hiemalis differed with respect to their growth capacity in the same carbon or nitrogen source in Bioscreen C. The results for the growth of strains M1, M2, M3, and M4 in the various culture media are presented in Figs. 1 to 3.

For each type of culture, the correspondent control indicated secondary contamination and provided correct interpretation of the microorganisms' growth in the culture medium. The occurrence of contamination may be explained by the growth speed of filamentous fungi usually slower than yeasts and bacteria. While the maximum number of bacteria or yeast is reached at 6 hours of cultivation due to the rapid and easy growth in liquid culture media (3), the Mucor strains reach the log phase at approximately 60 hours of culture.

The automated Bioscreen $\mathrm{C}$ system proved to be very convenient for obtention of cultures in liquid media, because it is rapid and automated, providing a good technique for the determination of the optimal environmental factors for growth of filamentous fungi, or to investigate their potential to produce fatty acids.
Bioscreen $\mathrm{C}$ was also used to test the ability of food-related Penicillium species and Geotrichum candidum grown on Czapek Dox and brie agar to suppress growth of pathogenic bacteria, using the same incubation conditions used in the present study $\left(\mathrm{t}=30^{\circ} \mathrm{C}\right.$ and $\left.\lambda=600 \mathrm{~nm}\right)$. The results demonstrated that the automatized system was excelent for antagonistic activity test (4).

Another study used Bioscreen C to compare the growth of mutants and wild-type strains of Rhodobacter sphaeroides in synthetic media containing lactic acid and in media resulting from the acidogenic fermentation of fruit and vegetable wastes. The work demonstrated the feasibility of the use of engineered microorganisms to improve biohydrogen photo production using waste-derived substrates (2).

The results of the present study showed that sodium acetate, used as a single carbon source in culture medium, was a growth inhibitor for the Mucor strains. The Friedman test rejected the equality of the groups for each strain. It was possible to verify that the strains formed distinct groups according to the culture media: M1 formed 5 groups, M2 formed 6 groups, M3 formed 4 groups, and M4 formed 7 groups (5\% significance). The Friedman test demonstrated that the differences in the growth of M1, M2 and M3 strains in different nitrogen and carbon sources were not significant. Only growth of the M4 strain was statistically different when compared to the other strains (Table 1).

The best carbon source for growth depended on the strain. For strains M1, M2 and M3 the best nitrogen source was yeast extract, and for strain M4 peptone was the best nitrogen source. The media containing potassium nitrate or ammonium sulfate

Table 1. Statistically significant differences (*), in $\alpha=5 \%$, for groups comparison of Mucor hiemalis strains, through the Friedman Test.

\begin{tabular}{|c|c|c|c|c|c|c|}
\hline \multirow{2}{*}{$\begin{array}{l}\text { Nutritional } \\
\text { Sources }\end{array}$} & \multicolumn{6}{|c|}{ Mucor hiemalis strains } \\
\hline & M1M2 & M1M3 & M1M4 & $\mathrm{M} 2 \mathrm{M} 3$ & M2M4 & M3M4 \\
\hline \multicolumn{7}{|l|}{ Ammonium } \\
\hline sulphate & $*$ & $*$ & $*$ & & $*$ & $*$ \\
\hline Fructose & & & $*$ & & * & $*$ \\
\hline Galactose & & & $*$ & & $*$ & $*$ \\
\hline Glucose & & & $*$ & & * & $*$ \\
\hline Glycerol & & & $*$ & & $*$ & \\
\hline Lactose & & & $*$ & & $*$ & $*$ \\
\hline Maltose & & & $*$ & & $*$ & $*$ \\
\hline Peptone & & & $*$ & & & \\
\hline Sodium acetate & & & $*$ & & $*$ & $*$ \\
\hline Sorbitol & & $*$ & $*$ & $*$ & $*$ & \\
\hline Sucrose & & & $*$ & $*$ & $*$ & $*$ \\
\hline Xylose & & & $*$ & & $*$ & $*$ \\
\hline Yeast extract & & & & & & \\
\hline
\end{tabular}




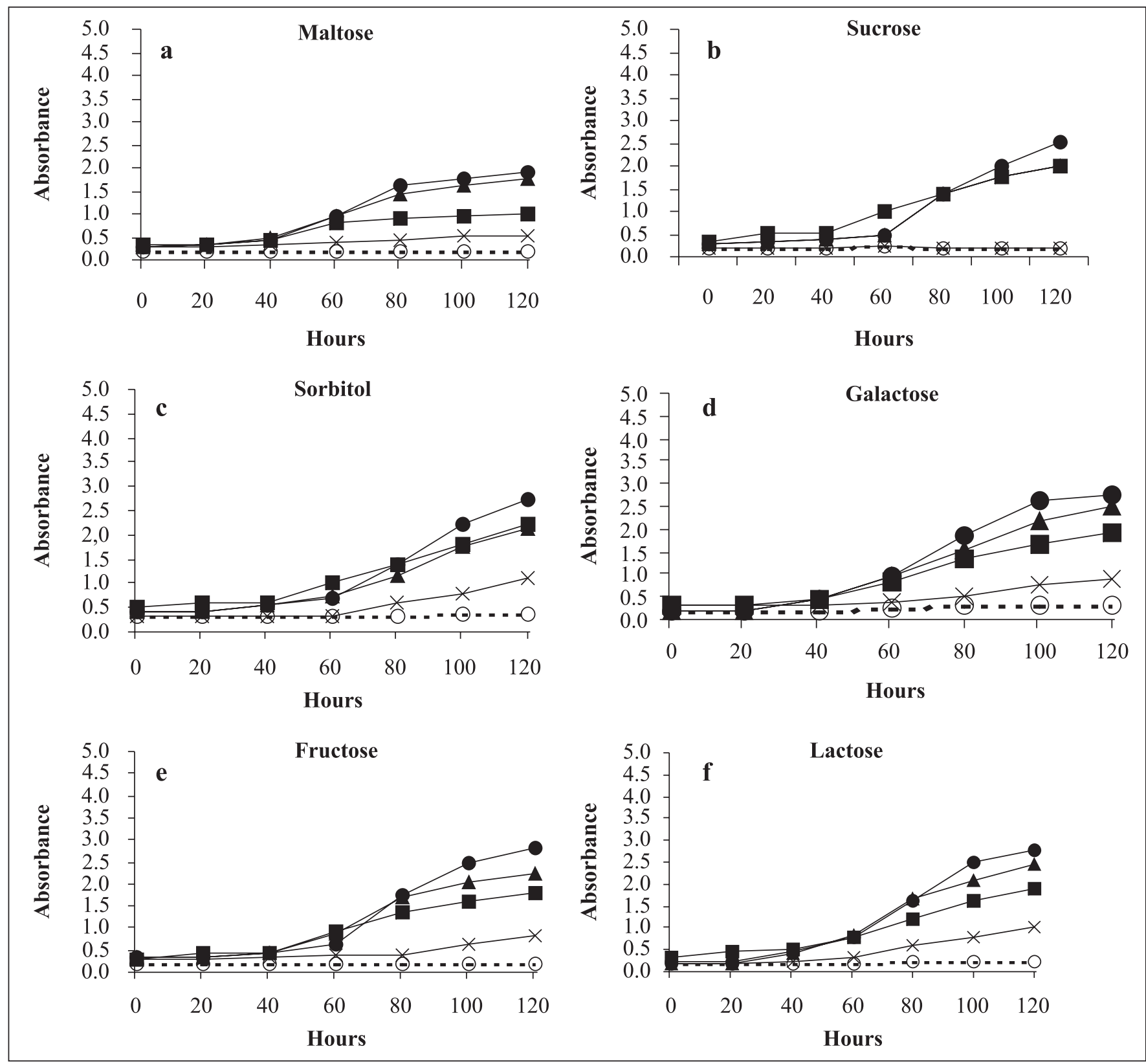

Figure 1. Growth curves of Mucor hiemalis strains M1 (O), M2 ( $\mathbf{\square}), \mathrm{M} 3(\mathrm{O})$, and M4 (x) in medium containing only one carbon source as maltose (a), sucrose (b), sorbitol (c), galactose (d), fructose (e) and lactose (f), incubated at $25^{\circ} \mathrm{C}$ for 120 hours in an automated Bioscreen $\mathrm{C}$ system. $\mathbf{\Delta}=$ control

resulted in little growth of all strains. The M4 strain showed better growth than the other strains in medium containing glucose or maltose as the only carbon source.

The carbon sources that caused better growth of the strains were: strain M1: fructose, galactose, glycerol, lactose, sorbitol and xylose; M2: sorbitol and sucrose and M3: fructose, galactose, glycerol, lactose and maltose; M4: galactose, glycerol and sorbitol.
The results demonstrate that the four strains of Mucor hiemalis grow differently in different carbon and nitrogen sources under the same culture conditions. The best sources of carbon depended on the strain, while yeast extract proved to be the best nitrogen source for growth of all strains. The automatized Bioscreen $\mathrm{C}$ system facilitated the choice of the best nutritional source, saving time and amount of reagents. 


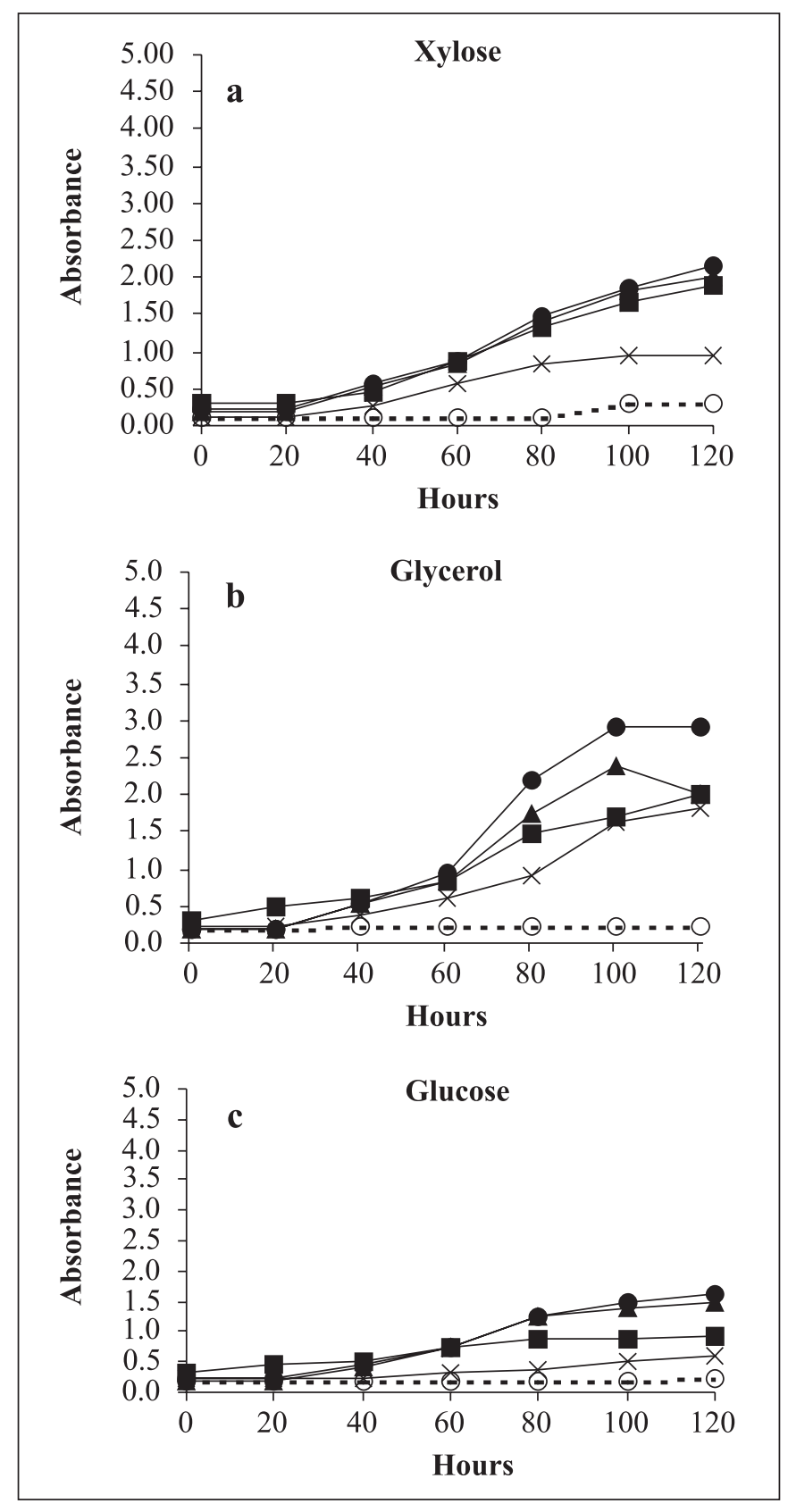

Figure 2. Growth curves of Mucor niemalis strains M1 ( $)$, M2 ( $\mathbf{\square})$, M3 ( $\boldsymbol{\Delta})$, and M4 (x) in medium containing only one carbon source as xylose (a), glycerol (b) and glucose (c), incubated at $25^{\circ} \mathrm{C}$ for 120 hours in an automated Bioscreen $\mathrm{C}$ system. $\mathbf{\Delta}$ = control.

\section{ACKNOWLEDGEMENTS}

The authors thank Anne Kepple for the language revision and FAPESP and FUNDUNESP for the financial support.
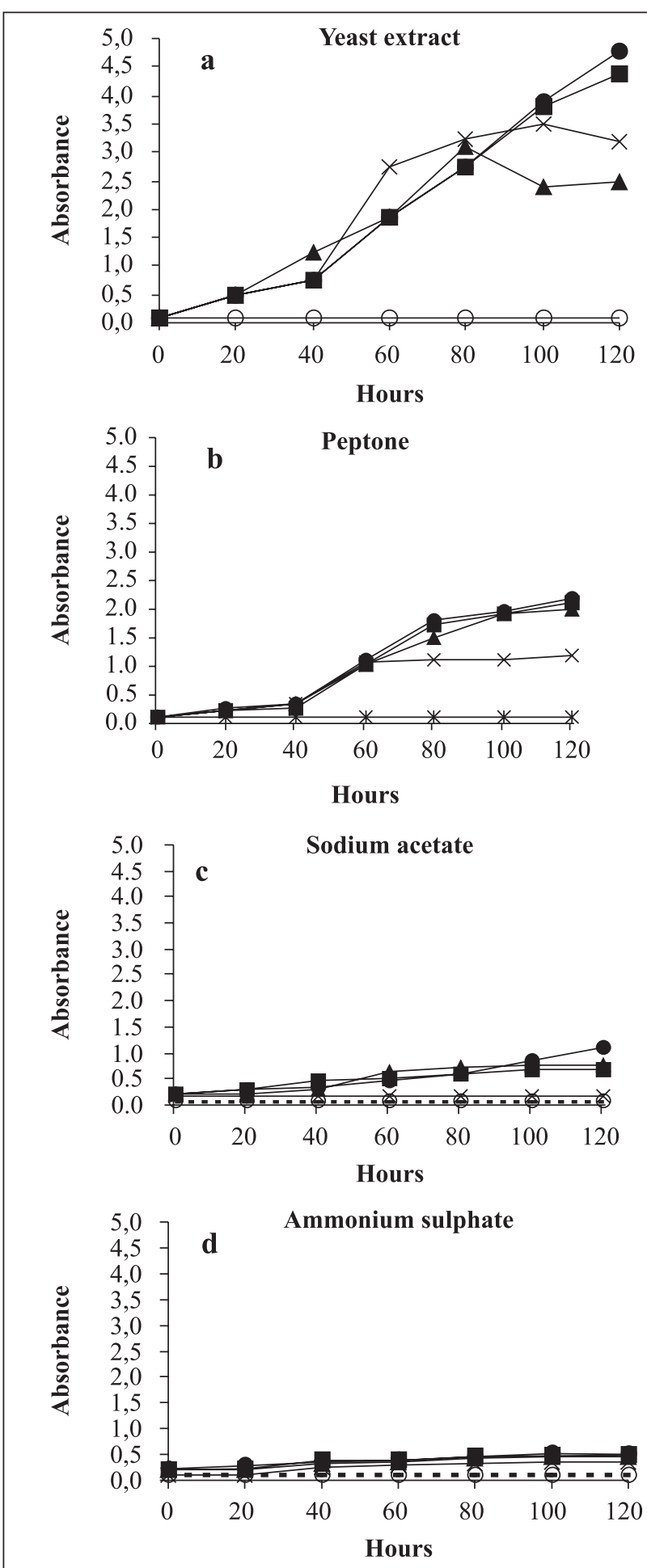

Figure 3. Growth curves of Mucor hiemalis strains M1 ( $)$, M2 ( $\square$ ), M3 ( $\mathbf{\Delta})$, and M4 (x), in medium containing 1\% glucose and only one nitrogen source as yeast extract (a), peptone (b) and sodium acetate (c), incubated at $25^{\circ} \mathrm{C}$ for 120 hours in an automated Bioscreen $\mathrm{C}$ system. $\mathrm{O}=$ control. 


\section{RESUMO}

\section{Uso do Bioscreen C para crescimento de Mucor hiemalis em diferentes fontes de carbono e nitrogênio}

O sistema automatizado Bioscreen $\mathrm{C}$ foi utilizado para o crescimento de quatro linhagens de Mucor hiemalis, isoladas do solo da Estação Ecológica de Juréia-Itatins (EEJI), estado de São Paulo, em meios líquidos com uma única fonte de carbono ( $2 \%$ ) ou de nitrogênio ( $1 \%), \mathrm{pH} 5,0$, a $25^{\circ} \mathrm{C}$, e agitação de $150 \mathrm{rpm}$ por 5 dias. $\mathrm{O}$ meio com somente uma única fonte de nitrogênio foi adicionado com $2 \%$ de glicose. As leituras de densidade óptica foram realizadas a $540 \mathrm{~nm}$, em intervalos de $2 \mathrm{~h}$, por cinco dias. Os resultados foram analisados estatisticamente com o Teste de Friedman $(\alpha=5 \%)$. Os melhores crescimentos foram obtidos com as linhagens M1, M2 e M3, que atingiram o início da fase $\log$ em 60 horas de cultivo. As melhores fontes de carbono variaram de acordo com a linhagem estudada, e extrato de levedura provou ser a melhor fonte de nitrogênio para todas as linhagens. Acetato de sódio inibiu o crescimento das quatro linhagens, sendo a M3 a mais afetada. O uso do sistema automatizado foi muito conveniente para as culturas em meio liquido, sendo rápido e automático, constituindo em uma boa técnica para a determinação das condições ambientais ótimas para crescimento de fungos filamentosos.

Palavras-chave: Mucor hiemalis, zigomicetos, sistema automatizado, fontes de carbono e nitrogênio

\section{REFERENCES}

1. Alvarez-Barrientos, A.; Arroyo, J.; Canton, R.; Nombela, C.; Sanchez-Pérez, M. (2000). Applications of flow cytometry to clinical microbiology. Clinical Microbiol. Rev., 13: 167-195.

2. Franchi, E. et al. Metabolically engineered Rhodobacter sphaeroides RV strains for improved biohydrogen photoproduction combined with disposal of food wastes. Mar. Biotechnol., Jan 17 (NY). 2005. \{Epub ahead of print

3. Johnston, M.D. (1998). A simple and rapid test for quality control of liquid media, using the bioscreen microbiological growth analyzer. J. Microbiol. Meth., 32: 37-43.

4. Larsen, A.G.; Knochel, S. (1997). Antimicrobial activity of foodrelated Penicillium sp. against pathogenic bacteria in laboratory media and a cheese model system. J. Appl. Microbiol., 83: 111-119.

5. Lisowska, K.; Palexz, B.; Dlugonski, J. (2004). Microcalorimetry as a possible tool for phenanthrene toxicity evaluation to eukaryotic cells. Thermochim. Acta., 411: 181-186.

6. Mattila, T.; O’Boyle, D.; Frost, A.J. (1988). The growth of compact and diffuse variants of Staphylococcus aureus in bovine mastitic and normal whey. Microbiol. Immunol., 667-673.

7. Ruegger, M.J.S.; Tauk-Tornisielo, S.M.; Pastore, G.M. (2002) Isolamento de fungos produtores de ácido $\gamma$-linolênico de solo da Estação Ecológica de Juréia-Itatins, SP. Rev. Ciên.Farm., 23: 49-58.

8. Stephens, P.J.; Joynson, J.A., Davies, K.W.; Holbrook, R.; LappinScott, H.M.; Humphey, T.J. (1997). The use of an automated growth analyser to measure recovery times of single heat injured Salmonella cells. J. Appl. Microbiol., 83: 445-455.

9. Tauk-Tornisielo, S.M.; Garlipp, A.; Ruegger, M.J.S.; Attili, D.S.; Malagutti, E.N. (2005). Soilborne filamentous fungi in Brazil. J. Basic Microbiol., 45: 72-82.

10. Wu, Y.; Griffiths, M.W.; McKellar, R.C. (2000). A comparison of the Bioscreen method and microscopy for the determination of lag times of individual cells of Listeria monocytogenes. Lett. Appl. Microbiol., 30: 468-472.

11. Zar, J.H. (1999). Biostatistical analysis. Prentice Hall, New Jersey, $4^{\mathrm{a}}$ Ed., $663 \mathrm{p}$. 